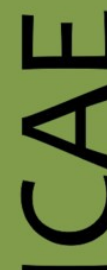

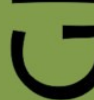

ex Instituto Archaeologico Universitatis de Rolando Eötvös nominatae

O

$\overrightarrow{0}$

山

$\leftarrow$

I

$\cup$

ه

$\leftarrow$

u

Ш

Z

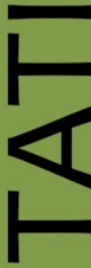

œ

ш

n

n

$\varnothing$
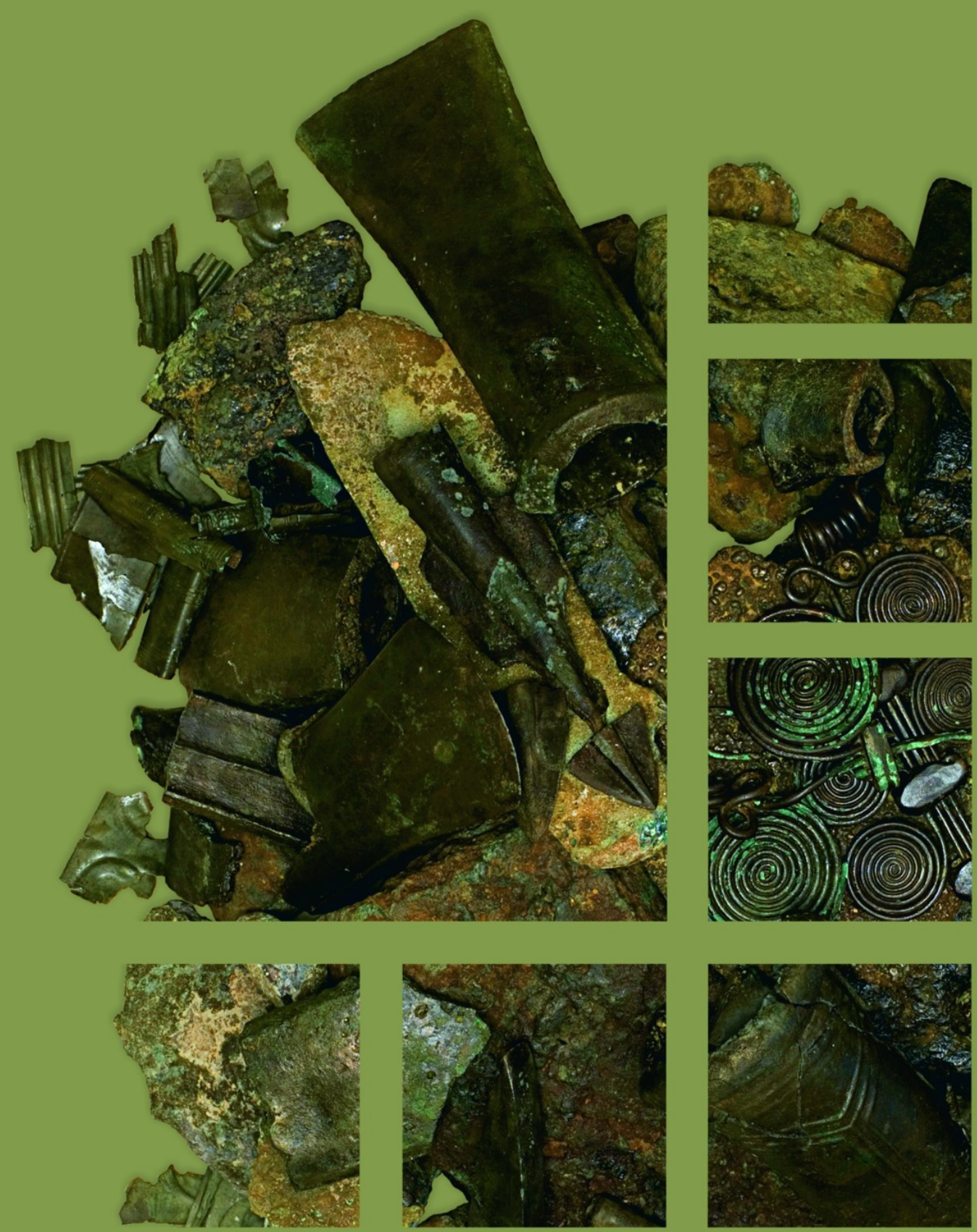


\section{Dissertationes Archaeologicae ex Instituto Archaeologico}

Universitatis de Rolando Eötvös nominatae Ser. 3. No. 2.

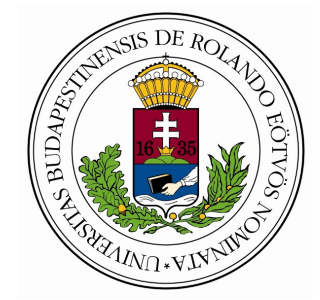

Budapest 2014 
Dissertationes Archaeologicae ex Instituto Archaeologico Universitatis de Rolando Eötvös nominatae

Ser. 3. No. 2.

Editor-in-chief:

DÁvid BARTus

Editorial board:

LÁsZló BARTOSIEWICZ

LÁSZLÓ BORHY

IsTVÁN FELD

GÁBOR KALLA

PÁL RACZKY

MiKLÓs SzABÓ

TIVADAR VIDA

Technical editors:

DÁvid BARTus

GÁBOR VÁCZI

ANDRÁs BÖDŐCS

DÁNIEL SZABÓ

Proofreading:

SZILVIA SzÖLLősI

Available online at http://dissarch.elte.hu Contact: dissarch@btk.elte.hu

$$
\begin{aligned}
& \text { PUBLIC } \\
& \text { KNOWLEDGE } \\
& \text { PROJECT }
\end{aligned}
$$

(c) Eötvös Loránd University, Institute of Archaeological Sciences

Budapest 2014 


\section{Contents}

\section{SElected PAPERS OF THE XI. Hungarian CONFERENCE on Classical Studies}

Ferenc BARNA

Venus mit Waffen. Die Darstellungen und die Rolle der Göttin in der Münzpropaganda

der Zeit der Soldatenkaiser (235-284 n. Chr.)

Dénes GABLER

A belsó vámok szerepe a rajnai és a dunai provinciák importált kerámiaspektrumában

Lajos MATHÉDESZ

Római bélyeges téglák a komáromi Duna Menti Múzeum gyújteményében

Katalin OtTOMÁNYI

Újabb római vicusok Aquincum territoriumán

Eszter SÜVEGH

Hellenistic grotesque terracotta figurines. Problems of iconographical interpretation

András SzABó

Some notes on the rings with sacred inscriptions from Pannonia

István VIDA

The coinage of Flavia Maxima Helena

\section{Articles}

Gábor TARBAY

Late Bronze Age depot from the foothills of the Pilis Mountains

Csilla SÁRó

Roman brooches from Paks-Gyapa - Rosti-puszta

András BöDőcs - Gábor KovÁcs - Krisztián ANDERKó

The impact of the roman agriculture on the territory of Savaria

Lajos JuHÁsz

Two new Roman bronzes with Suebian nodus from Brigetio

\section{FIELD REPORTS}

Zsolt MESTER - Norbert FARAGó - Attila KirÁLy

The first in situ Old Stone Age assemblage from the Rába Valley, Northwestern Hungary

Pál RACZky - Alexandra ANDERs - Norbert FARAgó - Gábor MÁRKus

Short report on the 2014 excavations at Polgár-Csőszhalom 
Preliminary Report on the first season of fieldwork in Berettyóúffalu-Szilhalom

Márton SzILÁgyi - András FüZESI - Attila VIRÁG - Mihály GASPARIK

A Palaeolithic mammoth bone deposit and a Late Copper Age Baden settlement and enclosure

Preliminary report on the rescue excavation at Szurdokpüspöki - Hosszú-dúlö II-III. (M21 site No. 6-7)

Kristóf FüLÖP - Gábor VÁcZI

Preliminary report on the excavation of a new Late Bronze Age cemetery

from fobbágyi (North Hungary)

Lőrinc TimÁr - Zoltán CzAJLik - András BöDőcs - Sándor PuszTA

Geophysical prospection on the Pâture du Couvent (Bibracte, France). The campaign of 2014

Dávid BARtus - László Borhy - Gabriella Delbó - Emese SzÁmadó

Short report on the excavations in the civil town of Brigetio (Szőny-Vásártér) in 2014

Dávid BARTus - László BorHy - Emese SzÁMADó

A new Roman bath in the canabae of Brigetio

Short report on the excavations at the site Szőny-Dunapart in 2014

Dávid BARTus - László Borhy - Zoltán CzAjlik - Balázs Holl -

Sándor PuszTA - László RuPNiK

Topographical research in the canabae of Brigetio in 2014

Zoltán CZAJLIK - Sándor BERECKI - László RUPNIK

Aerial Geoarchaeological Survey in the Valleys of the Mureș and Arieș Rivers (2009-2013)

Maxim MoRDovin

Short report on the excavations in 2014 of the Department of Hungarian Medieval

and Early Modern Archaeology (Eötvös Loránd University, Budapest)

Excavations at Castles Čabrad' and Drégely, and at the Pauline Friary at Sáska

\section{Thesis Abstracts}

Piroska Csengeri

Late groups of the Alföld Linear Pottery culture in north-eastern Hungary

New results of the research in Borsod-Abaúj-Zemplén County

Ádám Bíró

Weapons in the 10-11th century Carpathian Basin

Studies in weapon technology and methodology - rigid bow applications and southern import

swords in the archaeological material

Márta DARÓcZI-SzABó

Animal remains from the mid 12th-13th century (Árpád Period) village of Kána, Hungary

Károly BELÉNYESY

A 15th-16th century cannon foundry workshop in Buda

Craftsmen and technology of cannon moulding and the transformation of military technology

from the Renaissance to the Post Medieval Period 
István RINGER

Manorial and urban manufactories in the 17th century in Sárospatak

\section{BIBLIOGRAPHY}

László BORHY

565

Bibliography of the excavations in Brigetio (1992-2014) 


\title{
Topographical research in the canabae of Brigetio in 2014
}

\author{
DÁvid BARTuS \\ Institute of Archaeological Sciences \\ Eötvös Loránd University \\ bartusdavid@gmail.com
}

Zoltán CZAJLIK

Institute of Archaeological Sciences

Eötvös Loránd University

czajlik.zoltan@btk.elte.hu

\author{
LÁSZLÓ BORHY \\ Institute of Archaeological Sciences \\ Eötvös Loránd University \\ lborhy@hotmail.com
}

BALÁZS HOLL

National Heritage Protection Centre Hungarian National Museum holl.balazs@hnm.hu

SÁNDOR PUSZTA

Fractal Co.

fractal@fractal.hu

\author{
LÁsZLó RUPNIK \\ MTA-ELTE Research Group \\ for Interdisciplinary Archaeology \\ rupnik.laci@gmail.com
}

\begin{abstract}
The present article introduces a recently started project which aims at studying the topography of the canabae and legionary fortress of Brigetio using non-destructive methods such as aerial photography and different geophysical surveys. After a brief summary of earlier research, the methods and results of the topographical work carried out in 2014 will be discussed below.
\end{abstract}

\section{Introduction}

Although systematic excavations in Brigetio have been started in 1992, providing important results concerning the civil town, large scale comprehensive topographical research on the whole territory of the Roman town has been carrying out only since 2013 . The main objective of this recently started project is to study the topography of the canabae and legionary fortress of Brigetio (Fig. 1) using non-destructive methods such as aerial photography and geophysical survey, however, we use these methods in connection with our research in the civil town as well.

Recent results of the aerial photography in Brigetio with the history of research were published in $2013,{ }^{1}$ therefore only the previous geophysical surveys should be briefly summarized here. The first magnetometer measurements were made by S. Puszta in 1996 at the territory of the civil town (Szőny-Vásártér). Despite a lot of difficulties caused by the urban environment, a north-south road and some traces of the Roman buildings could be identified,

1 RUPNIK - CZAJLIK 2013. 
which were confirmed by the later excavations. ${ }^{2}$ Geophysical surveys have continued after a long break in 2013 at the same site, where traces of further buildings and some deep structures (cellars?) were identified by ground-penetrating radar. Another combined geophysical survey was made south of the canabae, in the vicinity of the so-called "Szőny-Füzitöicsatorna", where we tried to find - unsuccessfully for the time being - traces of the main north-south road leading out from the legionary fortress.

After these previous results, we have started in 2014 the systematic geophysical prospection of the canabae of Brigetio combining magnetic and GPR surveys with aerial photography (Fig. 2).

\section{Methods}

Topographical survey in Brigetio and its surroundings can be made under various field circumstances. The application possibilities of remote sensing methods in the interior zone of Szőny and the neighbouring industrial areas are limited, since the Hungarian-Slovakian state border and the minimum flying altitude of 300 metres should be taken into consideration during aerial photography. Ground penetrating survey is chiefly limited by the modern built environment, while magnetometer measurements are also interfered by electronic and industrial background noise. Accessibility of the outskirts area is also diverse: the smaller ploughlands in the territory of the canabae can be surveyed only periodically, while south of the ancient town our research is facilitated by easily approachable large-sized plots.

Considering the above-mentioned circumstances, we used the following technical equipment during the surveys in 2014:

- Aerial photography: Cessna 152 airplane, Nikon D300 camera and Nikkor 24-70 ED lens with direct GPS data recording. The analyzed images were assembled by means of high resolution orthophotos and geodetically measured, well-identifiable landmarks. Due to the above mentioned limiting circumstances, a DJI Phantom 2 drone with GoPro Hero 3 camera was also used for low-altitude aerial photography.

- Magnetometer measurements: GEM Systems GSM-19 Overhauser magnetometer (base station and mobile instruments, with sampling intervals of $0.5 \mathrm{sec}$ ) in horizontal variometer arrangement with a Trimble GeoXH dual-frequency GPS, with external geodetic antenna. Due to the dual-sensor arrangement, the point density inside lines was approximately $0,5 \mathrm{~m}$ with a line distance of $0,75 \mathrm{~m}$. Noise was extracted from the raw measurement data using various mathematical filtering methods (base correction, dynamic range compression, reduction-to-pole, downward continuation of potential field data, band filtering, optimal smoothing filtering, etc.).

- Ground penetrating radar survey: Geophysical Survey Systems SIR 2000 ground penetrating radar with 150, 300 and $900 \mathrm{MHz}$ antennas, point density inside lines was $0,04 \mathrm{~m}$ with a line distance of $0,5 \mathrm{~m}$. The cleaning and processing of data, as well as the production of data cubes and time slices were accomplished using internally developed software based on Fractal technology. 


\section{Results}

The main aim of the first survey in 2014, which was a magnetometer prospection between 25th February and 7th March, was the further examination of the street-plan of the canabae discovered earlier by aerial photography. Another objective was to carry out measurements in a parcel south of the above-mentioned territory, where remote sensing was hitherto unsuccessful. The prospection of ca. 4,3 hectares confirmed several presumed elements of the street-plan, showing anomalies indicating massive stone buildings (Fig. 3), while at the southern part of the prospected territory ditches with the same orientation were found, providing very important data on the settlement structure of this part of the canabae (Fig. 4).

Since conventional aerial photography is suitable for exploration of relatively large areas, our research was not limited to Brigetio and its adjacent areas, but extended to the Ács Almásfüzitő - Tata triangle, considering the presumed Roman aqueduct between Tata and Brigetio. During the first survey (13th March) soil marks of linear features were recorded, which can be mainly identified as roads, however, ditches found earlier by magnetometer measurements were also confirmed analysing the photos (Fig. 4). Although the best suitable period for identifying cropmarks is early summer, our second survey (18th June) resulted in a few, hardly detectable information due to the unusually abundant rainfall. Despite of the circumstances rather good results were obtained, due to the roughly same sowing-time of the cereals on the small parcels around the "Szőny-Füzitői-csatorna" and between Ujjszőny and the oil refinery. Thus, our previous information on the legionary fortress and some parts of the canabae, based mainly on negative cropmarks, was now considerably augmented by positive cropmarks. Among others, a lower built-up density of the southern part of the canabae can be presumed particularly with semi-subterranean structures besides a few stone buildings.

The aim of the ground penetrating radar survey (15th July) was to find an area suitable for later archaeological excavations in that part of the canabae, where our earlier research indicated stone-built structures. After the evaluation of the data, the most interesting results were a T-junction north from the area measured earlier by magnetometer, and the northwestern part of the GPR survey area, where two or three coherent stone buildings were identified (Fig. 3).

The northernmost part of the canabae was also surveyed in 2014, in the frame of an excavation project preceding the construction of the flood-protection dam between Komárom and Almásfüzitő. ${ }^{3}$ Due to the alteration of the original plans the site was saved from being destroyed by the construction work, however, the top layers of soil had been already removed from an area of approximately $7000 \mathrm{~m}^{2}$. Low-altitude aerial photographic survey was carried out in this territory, where several massive stone buildings could be identified (Fig. 5).

The most important conclusions which can be drawn from the results of the research in 2014 is that quick and detailed survey of relatively large areas can be achieved by appropiate organization and continuous evaluation of the recorded data. Using different methods as control or supplemental application demonstrated that topographical research in other zones of the ancient Brigetio can also be accelerated and the background of later fieldwalking and excavations can be established.

3 See the short report on the excavation of the newly discovered Roman bath in the present volume: BARTUS - BORHY DELBó - SzÁmAdó 2014. 


\section{Acknowledgements}

The research was supported by the Hungarian Scientific Research Fund (OTKA K 108 667). Participants of the surveys were András Bödőcs, Gabriella Delbó, Katalin Groma and Nikoletta Sey, besides the authors of the present article.

\section{References}

Bartus, D. - Borhy, L. - Delbó, G. - SzÁmadó, E.: A new Roman bath in the canabae of Brigetio. Short report on the excavations at the site Szőny-Dunapart in 2014. Dissertationes Archaeologicae Ser. 3. No. 2, 437-449.

RupNik, L. - CzAjLIK, Z. 2013: Aerial archaeological survey of the legionary camp and military town at Brigetio. In: Czajlik, Z. - BöDőcs, A. (eds.): Aerial Archaeology and Remote Sensing from the Baltic to the Adriatic. Selected Papers of the Annual Conference of the Aerial Archaeology Research Group, 13th-15th September 2012, Budapest, Hungary. Budapest, 71-78, Pl. 11-12.

Doвosi, L. 2014: Városi lakóházépitészet Brigetióban. A Komárom/Szőny-Vásártér lelóhelyen 1992-2013 között folytatott ásatások épitészeti vonatkozású eredményei. Acta Archaeologica Brigetionensia Ser. I. Vol. 6. Komárom.

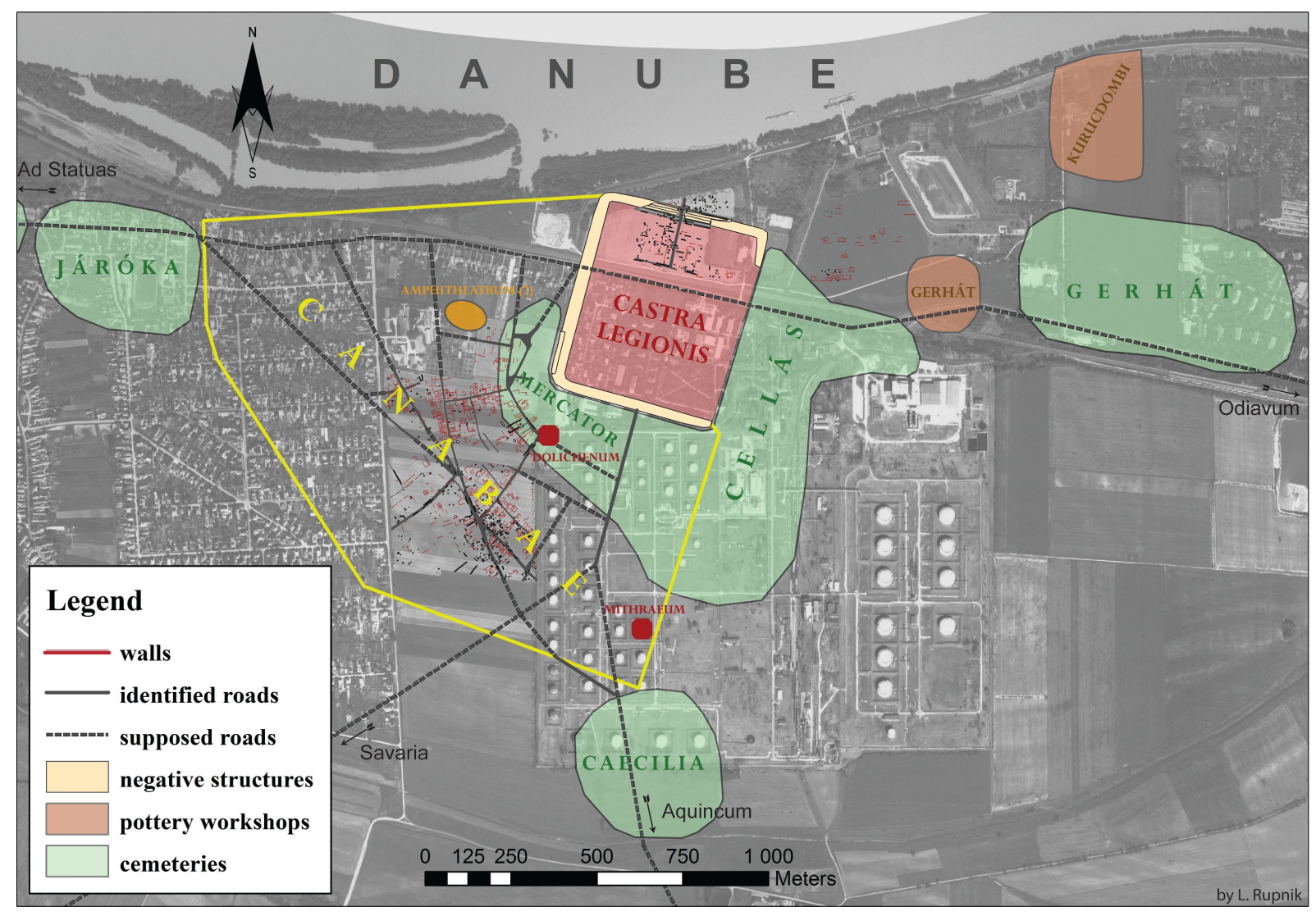

Fig. 1. The topography of the canabae and the legionary fortress. 


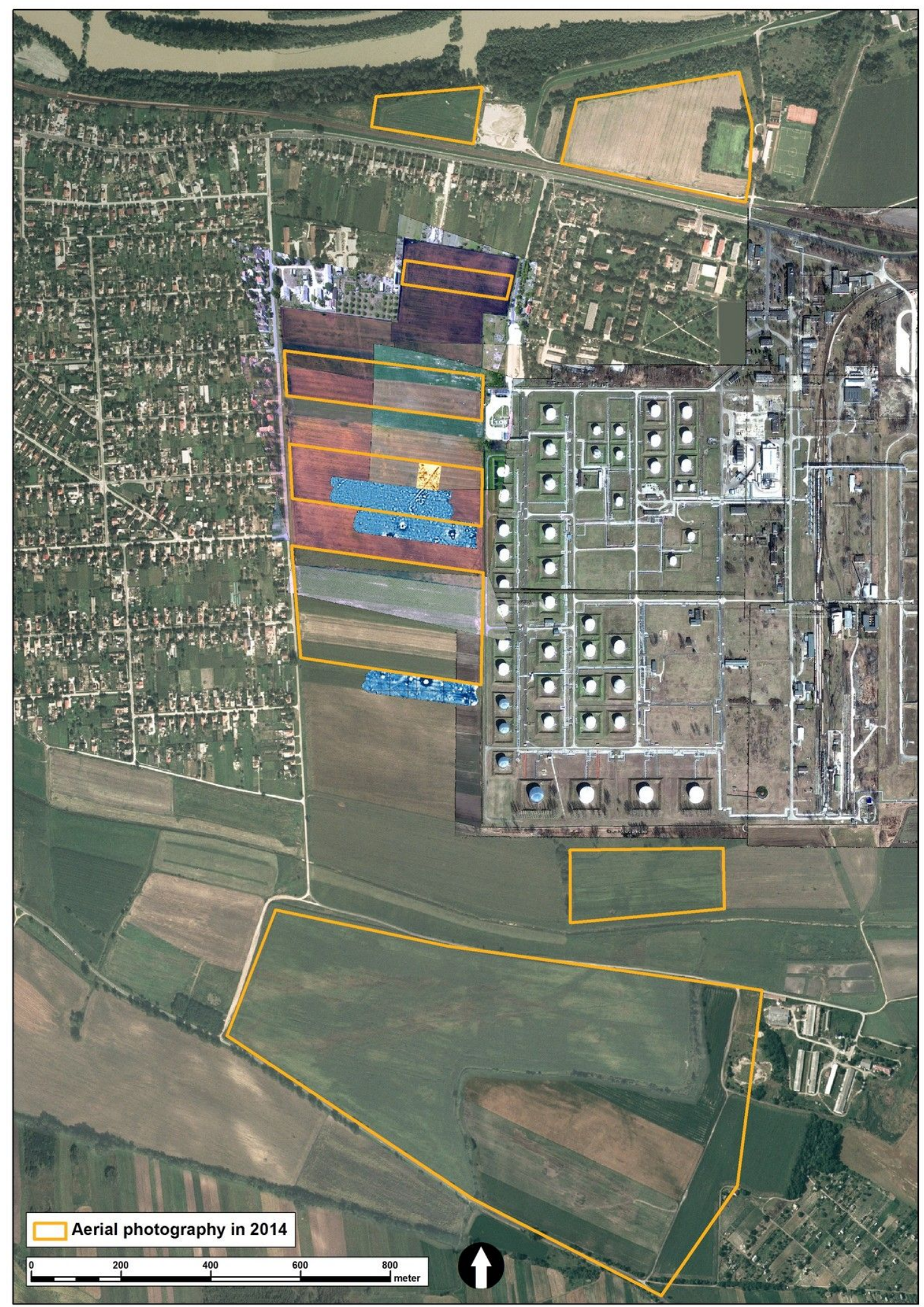

Fig. 2. Remote sensing topographical work in the area of the canabae. 


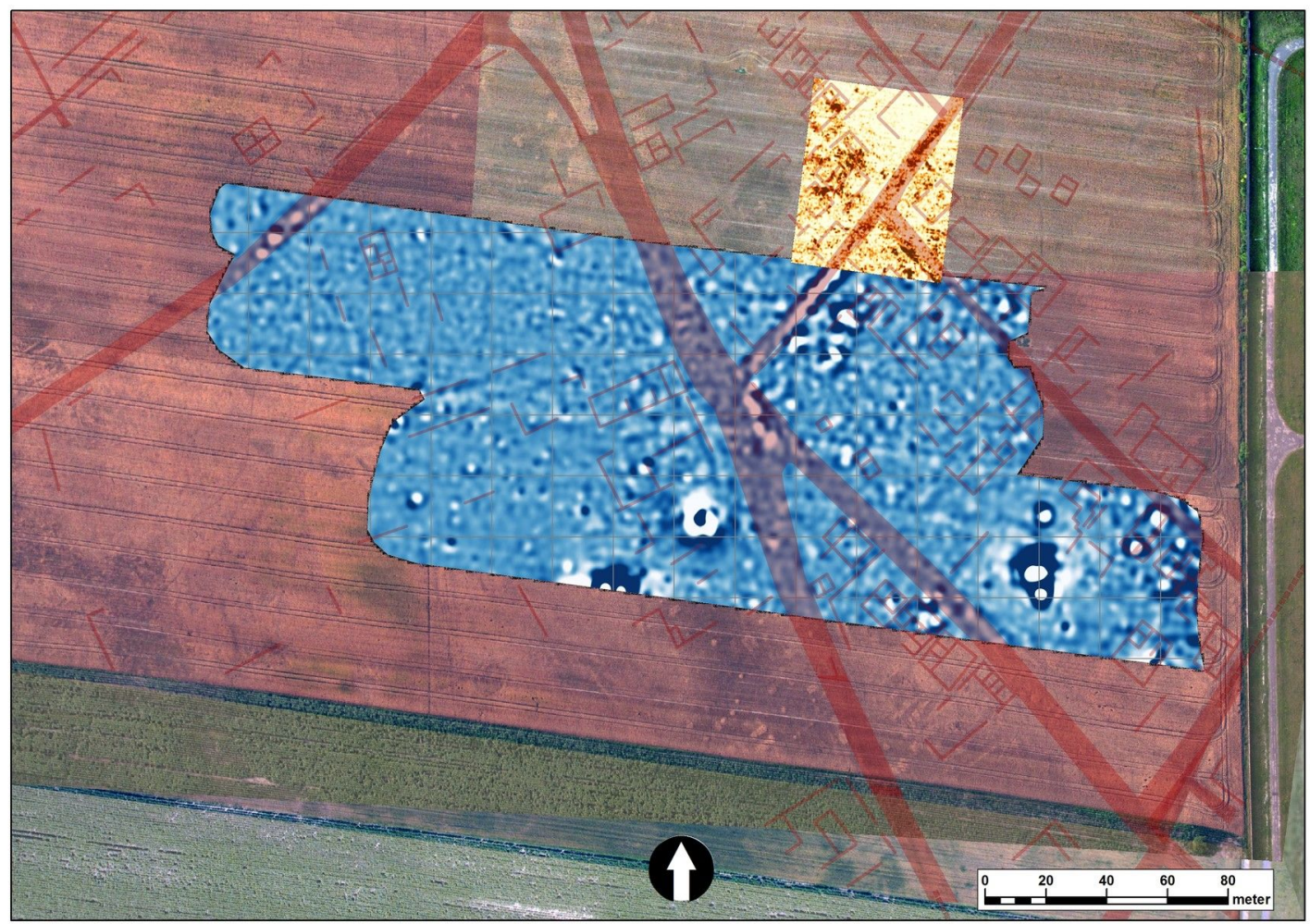

Fig. 3. Remote sensing topographical work at the northern part of the canabae. Magnetometer measurements (blue), GPR survey and aerial photography (brown).

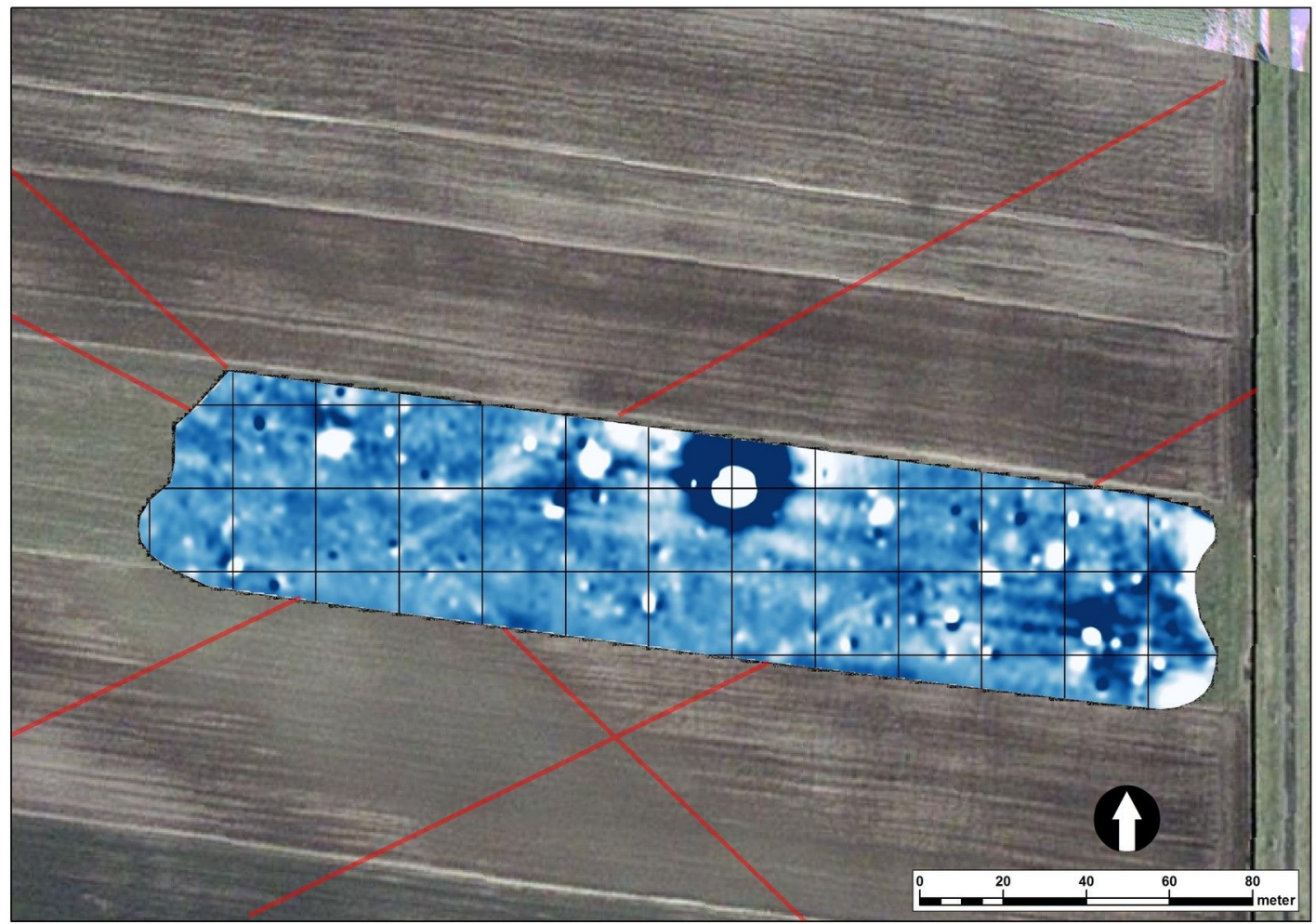

Fig. 4. Magnetometer survey at the southern part of the so-called "Pannonia-dülo". Linear structures parallel with the street-plan of the canabae are visible. 
D. Bartus - L. Borhy - Z. Czajlik - B. Holl - S. Puszta - L. Rupnik: Topographical research...

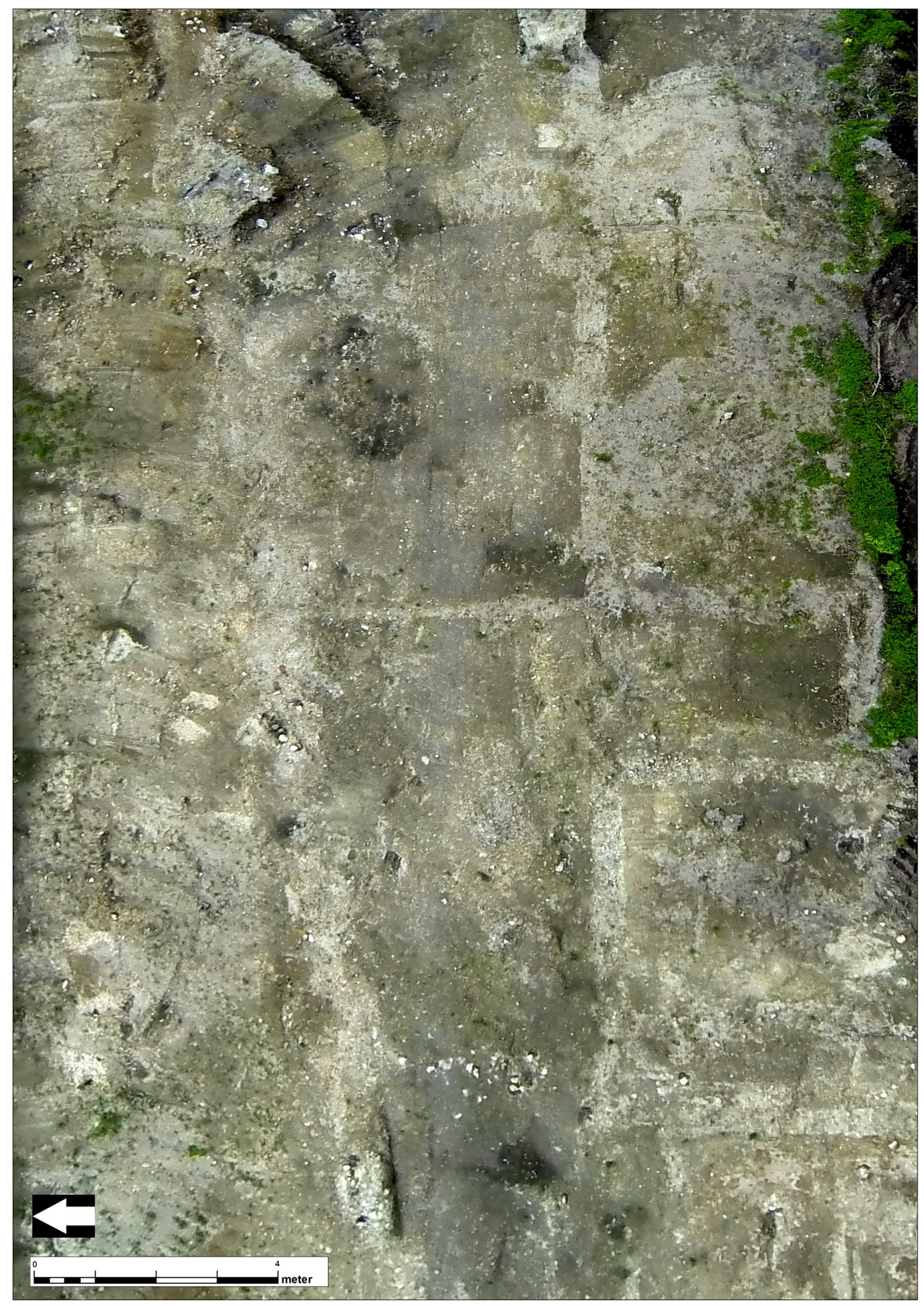

Fig. 5. Traces of stone buildings at the site Szőny-Dunapart.

The photo was taken of the unexcavated area after the removal of the top soil (Photo: Zs. Varga). 